\title{
GMR
}

\section{Intraspecific differentiation of Hancornia speciosa revealed by simple sequence repeat and random amplified polymorphic DNA markers}

C.A. Nogueira ${ }^{1}$, N.B. Stafuzza², T.P. Ribeiro ${ }^{3}$, A.D.L. Prado 3 , I.P.P. Menezes ${ }^{4}$, N. Peixoto ${ }^{3}$, P.J. Gonçalves ${ }^{5}$ and L.M. Almeida ${ }^{1}$

1Universidade Estadual de Goiás, Campus Anápolis de Ciências Exatas e Tecnológicas, Anápolis, GO, Brasil

2Departamento de Ciências Exatas, Faculdade de Ciências Agrárias e Veterinárias, Universidade Estadual de São Paulo "Júlio de Mesquita Filho",

Jaboticabal, SP, Brasil

${ }^{3}$ Universidade Estadual de Goiás, Campus Ipameri, Ipameri, GO, Brasil

${ }^{4}$ Laboratório de Genética e Biologia Molecular, Instituto Federal Goiano,

Urutaí, GO, Brasil

Instituto de Física, Universidade Federal de Goiás, Goiânia, GO, Brasil

Corresponding author: L.M. de Almeida

E-mail: almeidalm@hotmail.com

Genet. Mol. Res. 14 (4): 15996-16005 (2015)

Received March 10, 2015

Accepted July 23, 2015

Published December 7, 2015

DOI http://dx.doi.org/10.4238/2015.December.7.12

ABSTRACT. Hancornia speciosa, popularly known as mangabeira, is a fruit tree native to the Brazilian Cerrado that shows great economic potential, due to its multiple uses. Intraspecific classification of this species is difficult because it shows high morphological diversity. An early study of the species reported that there are six botanic varieties that differ morphologically mainly in the shapes of their leaves and flowers. Except to note the wide morphological variation and economic potential of this species, few studies have been published about the genetic diversity of 
mangabeira. Knowledge of the genetic variability of this species among populations would be useful for genetic conservation and breeding programs. Therefore, we tested the transferability of 12 simple sequence repeats from expressed sequence tags (EST-SSRs) from Catharanthus roseus to $H$. speciosa and used 10 random amplified polymorphic DNA markers to evaluate the genetic variability among botanical varieties of $H$. speciosa. We obtained a high transferability frequency of EST-SSR markers from $C$. roseus to $H$. speciosa (75\%). However, EST-SSR markers showed low heterozygosity and locus variability (two or three alleles by locus), which suggest low genetic diversity in the mangabeira samples. The Jaccard dissimilarity index and an examination of geographic distances indicated a non-spatial structuring of the genetic variability. Our markers were unable to distinguish $H$. speciosa botanical varieties.

Key words: Cerrado; Genetic variability; Hancornia speciosa; Mangabeira; Molecular markers; Transferability frequency

\section{INTRODUCTION}

Hancornia speciosa Gomes, commonly known as "mangabeira", is a plant species found in the Brazilian Cerrado or savanna-like vegetation. Interest in cultivating mangabeira for fruit production has been growing in recent years. Although the fruits are considered the main commercial product, other products from mangabeira have commercial value or at least potential. For example, the extract obtained from the leaves can have a hypotensive effect (Ferreira et al., 2007a,b; Silva et al., 2011). Different flavonoids, catechins, anthocyanins, and tannins extracted from the bark may be used to treat the gastritis caused by Helicobacter pylori (Moraes et al., 2008) or to stimulate liver functions and help treat diabetes, hypertension, and dermatitis (Ritter et al., 2002; Macedo and Ferreira, 2004). Recently, the latex from this species was shown to have antiinflammatory (Marinho et al., 2011) and angiogenic properties (Almeida et al., 2014).

Despite the pharmacological and economic potential of this species, there are few commercial plantations in Brazil and most of the harvested fruit comes from extractive activity (Carvalho et al., 2002). This activity, in addition to expanding agricultural frontiers (WWF, 2011), has reduced the distribution of $H$. speciosa in the Brazilian Cerrado, which may reduce the genetic variability of the species due to founder or bottleneck effects (Young et al., 1996). Thus, genetic conservation programs are necessary to maintain the diversity of this species.

Mangabeira belongs to the class Dicotyledoneae, order Gentianales, family Apocynaceae, and genus Hancornia. The genus includes only one species, Hancornia speciosa. According to Monachino (1945), there are six botanical varieties of mangabeira that differ mainly in the shapes of their leaves and flowers: Hancornia variety speciosa speciosa, maximilliani, lundii, cuyabensis, gardneri, and pubescens. As the classification of these varieties is performed exclusively by morphological characteristics, it is very difficult to identify different strains and classify samples accurately (Moura, 2003).

The success of any breeding or genetic conservation program depends on understanding the amount and distribution of the genetic variation in the species genome. Traditionally, genetic diversity has been measured by examining a combination of morphological and agronomic traits. 
However, $H$. speciosa is a heterogeneous plant with many overlapping morphological attributes. In addition, many vegetative characteristics are influenced by environmental factors and show continuous variation and high plasticity, which make it difficult to identify discrete taxonomic groups. Using molecular markers can overcome these problems and allow the monitoring of genetic variability (Gonzalés-Pérez et al., 2009; de Menezes et al., 2014; Song et al., 2014).

Microsatellite markers (SSRs) have been widely used to answer questions related to population genetics (Gonzalés-Pérez et al., 2009; Madesis et al., 2014; Wang et al., 2014). However, microsatellites are expensive to use and it is time-consuming to develop specific primers for each locus of the native species (Zucchi et al., 2002). In many studies, primers designed for one species have been used in other species within the same genus or even belonging to different genera, demonstrating their transferability (Fan et al., 2013; Mathithumilan et al., 2013). SSRs from expressed sequence tags (EST-SSRs) are markers that may be used between species belonging to different genera. The EST provides a source of polymerase chain reaction (PCR)-based markers for SSR direction (Wang et al., 2014). In the present study, we evaluated the transferability of EST-SSR markers described for Catharanthus roseus to H. speciosa. C. roseus belongs to the same family as mangabeira and EST-SSR markers from C. roseus have been transferred to other medicinal plants (Mishra et al., 2011).

We also evaluated another type of molecular marker, random amplified polymorphic DNA (RAPD). This is a good option for species whose genetics have not been characterized, like mangabeira; only six DNA sequences of $H$. speciosa have been deposited in GenBank (http://www. ncbi.nlm.nih.gov/genbank/). The use of RAPD markers also requires a lower level of skill and costs less per assay, and primers are readily available, allowing the entire genome to be scanned and the genotype to be characterized (Li et al., 2012).

The main objective of this research was to generate information for the future conservation, domestication, and breeding of mangabeira. Our specific goals were to 1) evaluate the transferability of microsatellite markers of $C$. roseus to $H$. speciosa; 2) estimate the genetic diversity of the species and determine whether genetic variation was related to geographical distribution; and 3) estimate the genetic relationships among different botanical varieties of $H$. speciosa.

\section{MATERIAL AND METHODS}

\section{Plant material}

A total of 34 leaf samples were collected in 27 locations in the Brazilian Cerrado, covering nine states (Figure 1). The leaves were transported to the laboratory for lineage identification and DNA extraction. DNA from young leaves was extracted using a modified cetyltrimethylammonium bromide procedure (Pan et al., 2006). DNA concentration and quality was estimated electrophoretically and spectrophotometrically by Nanodrop (Thermo Scientific).

\section{Oligonucleotide primers}

A total of 12 SSRs from C. roseus (Table 1) were tested in our experiments with mangabeira DNA. The primer sequences were developed by Mishra et al. (2011). For RAPD experiments, we tested four oligonucleotide primers that were previously used by Silva et al. (2011) in mangabeira and six oligonucleotide primers used by Lal et al. (2011) (Table 1). 


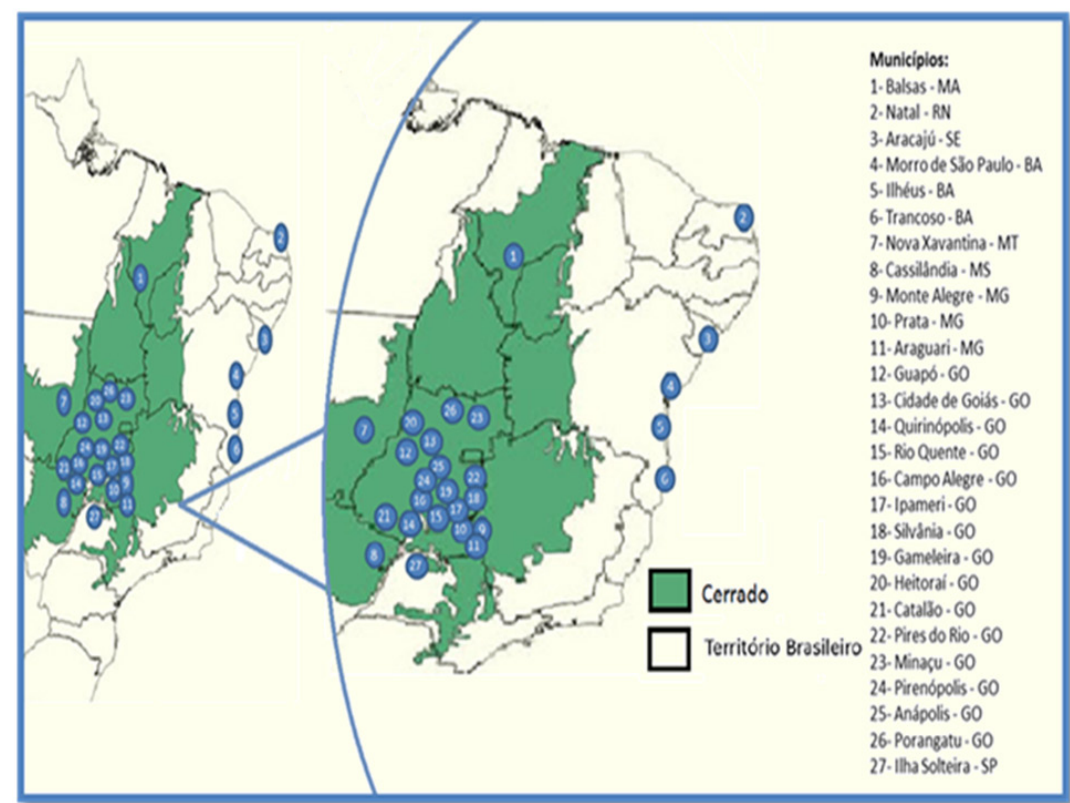

Figure 1. Hancornia speciosa geographic distribution in the Brazilian Cerrado biome (in green) and locations where the samples used in this study were collected.

\section{PCR analysis}

PCR was performed in an MJ Research PTC-200 thermocycler with the thermal gradient software to select the best annealing temperature for each marker. For EST-SSR experiments, PCR mixtures included $10 \mathrm{mM}$ Tris- $\mathrm{HCl}, 1.5 \mathrm{mM} \mathrm{MgCl}_{2}, 50 \mathrm{mM} \mathrm{KCl}, 10 \mathrm{mM}$ dNTPs, $0.2 \mathrm{mM}$ of each primer, $0.5 \cup$ AmpliTaq Gold Polymerase (Life Technologies ${ }^{\mathrm{TM}}$ ), and $50 \mathrm{ng}$ DNA in a $10-\mu \mathrm{L}$ reaction volume. The PCR conditions were as follows: initial denaturation at $94^{\circ} \mathrm{C}$ for $10 \mathrm{~min}$, followed by 35 cycles at $94^{\circ} \mathrm{C}$ for $30 \mathrm{~s}$ (denaturation), $50^{\circ}$ to $65^{\circ} \mathrm{C}$ for $30 \mathrm{~s}$ (annealing; the temperature depended on the individual microsatellite marker; Table 1), extension at $72^{\circ} \mathrm{C}$ for $30 \mathrm{~s}$, and a final extension at $72^{\circ} \mathrm{C}$ for $7 \mathrm{~min}$. RAPD experiments used the same PCR mixture, except $0.5 \mathrm{U}$ Taq Polymerase (Thermo Scientific) was used. The PCR conditions were as follows: initial denaturation at $94^{\circ} \mathrm{C}$ for $1 \mathrm{~min}$, followed by 35 cycles at $94^{\circ} \mathrm{C}$ for $30 \mathrm{~s}$ (denaturation), $40^{\circ}$ to $42^{\circ} \mathrm{C}$ for $30 \mathrm{~s}$ (annealing; the temperature depended on the individual microsatellite marker, Table 1), extension at $72^{\circ} \mathrm{C}$ for $30 \mathrm{~s}$, and a final extension at $72^{\circ} \mathrm{C}$ for $7 \mathrm{~min}$.

The PCR products were electrophoresed through $3 \%$ agarose gels in 1 XTBE buffer containing ethidium bromide and photographed under UV light. PCR products were scored 1 for present and 0 for absent amplification and the data were entered into a binary matrix as discrete variables.

\section{Data analysis}

The SSR and RAPD products were scored 1 for present and 0 for absent to determine the number of amplified fragments, polymorphic fragments, and percentage of polymorphism. Genetic diversity across 34 samples was calculated using the GENALEX 6.5 program (Peakall and Smouse, 
Table 1. Sequence of primers used for amplification of Hancornia speciosa DNA, using simple sequence repeats from expressed sequence tags (EST-SSRs) and random amplified polymorphic DNA (RAPD) markers.

\begin{tabular}{|c|c|c|c|c|}
\hline Marker & ID & Sequence & Annealing temperature $\left({ }^{\circ} \mathrm{C}\right)$ & Reference \\
\hline SSR-RG01 & gi|164561865 & $\begin{array}{l}\text { F: GGAACCAAGGATGTTAGAGTGG } \\
\text { R: CTGCAACGGTTACTAGAGAGTAGAGC }\end{array}$ & 50 & Mishra et al., 2011 \\
\hline SSR-RG04 & gi|164556897 & $\begin{array}{l}\text { F: CGTCAAGACCTACCCAGGAG } \\
\text { R: GTCTCCTCCGTCACCAGAAA }\end{array}$ & 50 & Mishra et al., 2011 \\
\hline SSR-RG05 & gi|164556756 & $\begin{array}{l}\text { F: CTGCTAGGCATGGTGGTGTAG } \\
\text { R: GATCCCAGCGGTGACTCTTA }\end{array}$ & 56 & Mishra et al., 2011 \\
\hline SSR-RG07 & gi|164556449 & $\begin{array}{l}\text { F: GAGGAGGTGTCTCTCATGCTG } \\
\text { R: CGACCTCAACAGAAGGTTCG }\end{array}$ & 50 & Mishra et al., 2011 \\
\hline SSR-RG08 & gi|164555839 & $\begin{array}{l}\text { F: AGAAGGAAGTGGTGGTGCTG } \\
\text { R: GTTTACAGGGGGAGGAGGAG }\end{array}$ & 56 & Mishra et al., 2011 \\
\hline SSR-RG11 & gi|164561349 & $\begin{array}{l}\text { F: GGCACGAGGCATCCTTACTC } \\
\text { R: CCACAGCTCTGGTAGCTCCT }\end{array}$ & 56 & Mishra et al., 2011 \\
\hline SSR-RG12 & gi|164561153 & $\begin{array}{l}\text { F: GGACAAGCTGGAGCAGCA } \\
\text { R: CTGCAACCAGAGGCTTCC }\end{array}$ & 50 & Mishra et al., 2011 \\
\hline SSR-RG13 & gi|164560959 & $\begin{array}{l}\text { F: CCGGAGGTGATGAGGTTCTG } \\
\text { R: GAGGCTGCTTTGGAGGAG }\end{array}$ & 56 & Mishra et al., 2011 \\
\hline SSR-RG15 & gi|164556819 & $\begin{array}{l}\text { F: GAGAGAGAGAGAGCGGCAAG } \\
\text { R: GTGGGTCTCCCACAATAGCG }\end{array}$ & 60 & Mishra et al., 2011 \\
\hline SSR-RG18 & gi|164561715 & $\begin{array}{l}\text { F: CATTCTCTTCTCGAGGCTTCTG } \\
\text { R: ACCCCCATGACAGTCAAGATAG }\end{array}$ & 53 & Mishra et al., 2011 \\
\hline SSR-RG21 & gi|164559832 & $\begin{array}{l}\text { F: CCCTTCCTGAGAGACTCAAATG } \\
\text { R: CCAAGCACTCTTCATCTCAGG }\end{array}$ & 53 & Mishra et al., 2011 \\
\hline SSR-RG30 & gi|164554493 & $\begin{array}{l}\text { F: GCCTCCAGTTACCCTTCCTC } \\
\text { R: ACAGCAGGATCACCAAGACC }\end{array}$ & 53 & Mishra et al., 2011 \\
\hline RAPD-ITD04 & - & TGATCCCTGG & 37 & Silva et al., 2011 \\
\hline RAPD-ITD11 & - & ACGGATCCTG & 37 & Silva et al., 2011 \\
\hline RAPD-ITD13 & - & CTACGGAGGA & 37 & Silva et al., 2011 \\
\hline RAPD-ITD14 & - & GGCACTGAGG & 37 & Silva et al., 2011 \\
\hline RAPD-OPA03 & - & AGTCAGCCAC & 42 & Lal et al., 2011 \\
\hline RAPD-OPC12 & - & TGTCATCCCC & 42 & Lal et al., 2011 \\
\hline RAPD-OPD20 & - & AACCCGGTCA & 42 & \\
\hline RAPD-OPN15 & - & CAGCGACTGT & 42 & Lal et al., 2011 \\
\hline RAPD-OPAF5 & - & CCCGATCAGA & 42 & Lal et al., 2011 \\
\hline RAPD-OPAF15 & - & CACGAACCTC & 42 & Lal et al., 2011 \\
\hline RAPD-ITD13/ITD11 & - & $\begin{array}{l}\text { CTACGGAGGA } \\
\text { ACGGATCCTG }\end{array}$ & 42 & Silva et al., 2011 \\
\hline RAPD-ITD13/ITD14 & - & $\begin{array}{l}\text { CTACGGAGGA } \\
\text { GGCACTGAGG }\end{array}$ & 42 & Silva et al., 2011 \\
\hline RAPD-ITD4/ITD11 & - & $\begin{array}{l}\text { TGATCCCTGG } \\
\text { ACGGATCCTG }\end{array}$ & 42 & Silva et al., 2011 \\
\hline RAPD- OPA03/ OPAF5 & - & $\begin{array}{l}\text { AGTCAGCCAC } \\
\text { CCCGATCAGA }\end{array}$ & 42 & Lal et al., 2011 \\
\hline
\end{tabular}

2012). The data matrix for the combined markers was used to calculate the dissimilarity matrix using the Jaccard coefficient, according to the method of Sneath and Sokal (1973) using the DARwin V5.0 program (Perrier and Jacquemoud-Collet, 2006). We determined the genetic relationships of 34 samples using a dendrogram based on the unweighted pair-group method of averages (UPGMA) with the MEGA5 program (Tamura et al., 2011). In addition, the cophenetic correlation was measured to evaluate the degree of fit of the clusters in the dendrogram to the data in the dissimilarity coefficient matrix. Principal component analysis (PCA) was applied to all genotypes for the clustering analysis.

\section{RESULTS}

\section{Morphological classification}

The samples included five of the six morphological lineages of $H$. speciosa, identified according to Monachino (1945). H. speciosa speciosa samples had glabrous leaves, petioles 0.9 
to $0.15 \mathrm{~cm}$ long, and leaf lamina up to $6 \mathrm{~cm}$ long and $2 \mathrm{~cm}$ wide. This botanical variety was collected in Natal (Rio Grande do Norte, RN), Aracaju (Sergipe, SE), Morro de São Paulo (Bahia, BA), Trancoso (BA), and Ilhéus (BA). H. speciosa gardineri samples had glabrous leaves, petioles from 0.3 to $0.5 \mathrm{~cm}$ long, and leaf blades 6 to $12 \mathrm{~cm}$ long and 3 to $6 \mathrm{~cm}$ wide. This botanical variety was collected in Guapó (Goiás, GO), Cidade de Goiás (GO), Quirinópolis (GO), Rio Quente (GO), Campo Alegre (GO), Ipameri (GO), Silvânia (GO), Heitoraí (GO), Catalão (GO), Pires do Rio (GO), Minaçu (GO), Pirinópolis (GO), Anápolis (GO), Porangatu (GO), and Ilha Solteira (São Paulo, SP). H. speciosa pubescens samples had short petioles, pubescent blades at the bottom, and leaves that were 6 to $12 \mathrm{~cm}$ long and 3 to $6 \mathrm{~cm}$ wide. This botanical variety was collected in Balsas (Maranhão, MA), Gameleira (GO), and Ipameri (GO). H. speciosa maximiliani samples had glabrous leaves, petioles about $0.8 \mathrm{~cm}$ long, and limbus 5 to $6 \mathrm{~cm}$ long and 2 to $2.5 \mathrm{~cm}$ wide. This botanical variety was collected in Prata (Minas Gerais, MG) and Araguari (MG). H. speciosa cuyabensis samples had petioles between 0.3 to $0.5 \mathrm{~cm}$ long, limbus 4 to $10 \mathrm{~cm}$ long and 1.5 to 3 $\mathrm{cm}$ wide, and calyx and corolla glabrous externally. This botanical variety was collected in Monte Alegre (MG). H. speciosa lundii samples had petioles 0.3 to $0.5 \mathrm{~cm}$ long, limbo 5 to $7 \mathrm{~cm}$ long and $3 \mathrm{~cm}$ wide, and pedicels pubescent. This botanical variety was collected in Nova Xavantina (Mato Grosso, MT) and Cassilândia (Mato Grosso do Sul, MS). Some samples were deposited at the State University of Goiás Herbarium (Universidade Estadual de Goiás, Anápolis, GO, Brazil).

\section{Transferability of microsatellite markers of $C$. roseus to $H$. speciosa}

The 12 primers tested were classified according to the PCR results: $75 \%$ (nine pairs of primers) amplified clear EST-SSR products, $16.7 \%$ presented nonspecific fragment amplification, and $8.3 \%$ did not amplify any fragments. Of the nine primer pairs that showed amplification, four were monomorphic and five were polymorphic. In all, 14 alleles were identified, ranging from two to three bands per locus. Table 2 showed the genetic characterization of five microsatellite loci in 34 mangabeira samples. While some of the heterozygous loci studied displayed a relative excess $\left(F_{\mathrm{IS}}<0\right)$ or deficiency $\left(F_{\mathrm{IS}}>0\right)$, the average genetic diversity $\left(H_{\mathrm{E}}=0.226 \pm 0.017\right)$ did not differ significantly from the observed heterozygosity $\left(H_{\mathrm{O}}=0.194, \pm 0039\right)$ when the standard error of the mean was considered. Thus, there was no standard or intra/interlocus distribution, as indicated by an average rate of inbreeding that did not differ from zero $\left(F_{\mathrm{IS}}=0.119 \pm 0.157\right)$.

\begin{tabular}{|c|c|c|c|c|c|}
\hline Locus & Alleles (bp) & $N_{\mathrm{A}}$ & $H_{\circ}$ & $H_{\mathrm{E}}$ & $F_{\text {IS }}$ \\
\hline RG07 & $159,177,193$ & 3 & 0.095 & 0.260 & 0.625 \\
\hline RG08 & $63,75,99$ & 3 & 0.273 & 0.255 & -0.119 \\
\hline RG12 & $113,177,195$ & 3 & 0.107 & 0.168 & 0.351 \\
\hline RG21 & 193,313 & 2 & 0.273 & 0.241 & -0.158 \\
\hline RG30 & $326,447,603$ & 3 & 0.222 & 0.205 & -0.106 \\
\hline Total & & 14 & 0.194 & 0.226 & 0.119 \\
\hline Standard deviation & & - & 0.039 & 0.017 & 0.157 \\
\hline
\end{tabular}

$N_{\mathrm{A}}=$ number of alleles; $H_{\mathrm{O}}=$ observed heterozygosity; $H_{\mathrm{E}}=$ expected heterozygosity; $F_{\mathrm{IS}}=$ inbreeding coefficient.

\section{Estimation of the genetic diversity of the species and association with geographical distribution}

Analysis of the Jaccard dissimilarity coefficients, calculated on the basis of the presence 
and absence of RAPD and EST-SSR markers, showed that the similarity coefficients were highly similar, indicating a high degree of association between the dendrogram cluster and dissimilarity matrices. Due to this result, both markers were used to estimate the genetic diversity. The average dissimilarity obtained was 0.80 , with an observed maximum dissimilarity of 1.0 and a minimum of 0.34 . The analysis between the genetic dissimilarity and geographic distance of $H$. speciosa from different regions was positively correlated but not significant (correlation coefficient $r=$ 0.17). Genetic cluster analysis was conducted using the UPGMA. Cluster analysis divided the 34 genotypes into six main groups (Figure 2). There was no correlation between genetic diversity and geographical distribution, as lineages collected from distant regions were grouped together. For example, samples from Bahia (Morro SP 1) and São Paulo (Ilha Solteira) were grouped with different samples from Goiás; samples from Maranhão (Balsas), Rio Grande do Norte (Natal), and Goiás (Guapó) were grouped with Minas Gerais (Monte Alegre); samples from Mato Grosso (Nova Xavantina) were grouped with Bahia (Morro SP2); and samples from Sergipe (Aracaju), Goiás (Pires do Rio), and Bahia (Trancoso) were grouped with Minas Gerais (Prata). This result suggested a non-spatial structuring of the variability for the different lineages of $H$. speciosa.

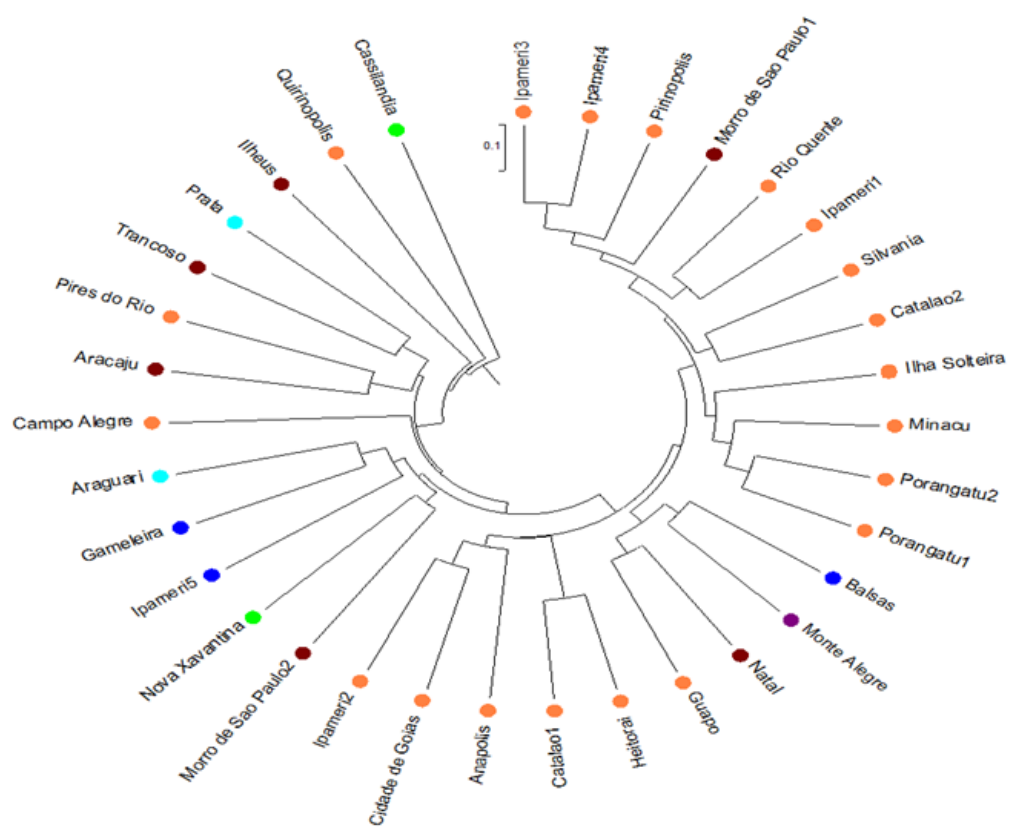

Figure 2. Genetic distance dendrogram for Hancornia speciosa samples, created using simple sequence repeat and random amplified polymorphic DNA markers.

\section{Assessment of the genetic relationships among different $H$. speciosa varieties}

Analysis of molecular variance and PCA were performed to evaluate the genetic variability among the botanical varieties. The molecular variance between the botanical varieties was not significant (0.03) and the PCA did not detect any differentiation among the botanical varieties (Figure 3). Therefore, the markers employed in this study were not able to distinguish variation as well the morphological traits could distinguish differences. 


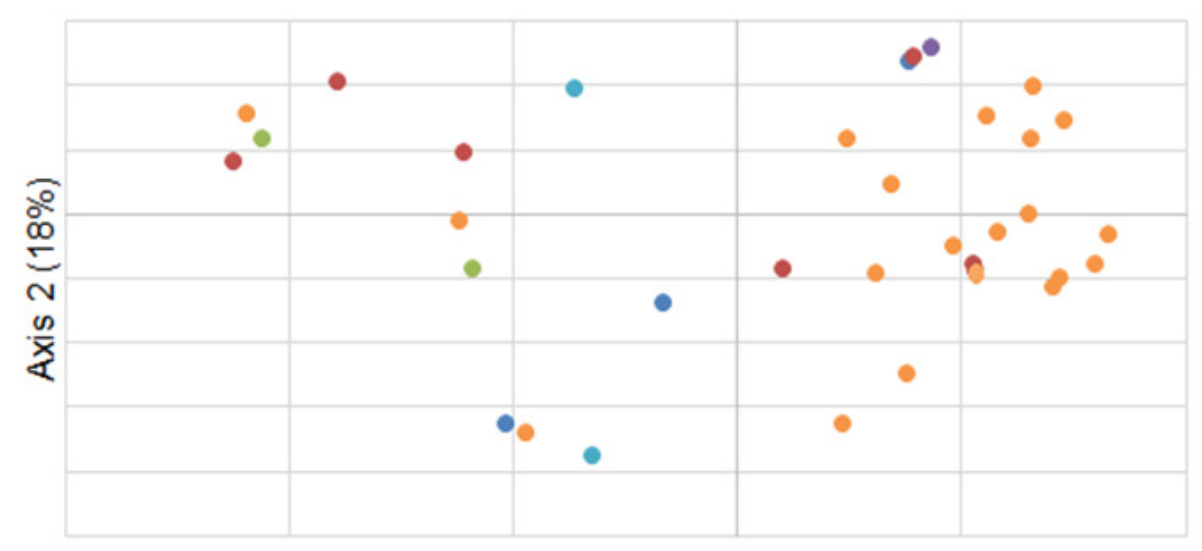

Axis $1(34.2 \%)$

- pubescens • speciosa • lundii • cuyabensis • maximiliani $\bullet$ gardneri

Figure 3. Genetic relationships among botanical varieties of Hancornia speciosa using principal component analysis.

\section{DISCUSSION}

The main objective of this study was to generate specific markers for use in future conservation and genetic improvement studies involving $H$. speciosa. To date, there have been very few studies of genetic diversity in mangabeira populations, and all of them use RAPD markers as the molecular tool (Moura et al., 2005, 2011; Costa et al., 2011; Silva et al., 2011) due to the absence of the species genome information. As noted, only six sequences of $H$. speciosa appear in the GenBank database. In addition, all the studies of $H$. speciosa that have been cited here based their analysis on regional or local samples and evaluated only small dispersion areas of this species. The present analysis, in contrast, used samples collected from an extent dispersion area that included nine Brazilian states.

One of our secondary objectives was to transfer SSR markers from $C$. roseus to $H$. speciosa. We used the EST-SSR markers described by Misha et al. (2011), which were selected due to their easy availability, hypervariability, and suitability for high throughput analysis, high polymorphism, and transferability compared with other available markers. Our EST-SSR results showed a high transferability frequency $(75 \%)$ of $C$. roseus to $H$. speciosa, which indicates that other SSR markers described by Misha et al. (2011) may be used to detect the genetic variability of $H$. speciosa. However, as the EST is a highly conserved DNA region, there is a high probability of finding low genetic variability among closely related species. Indeed, our results showed this low locus variability, with four monomorphic markers and five markers with two or three alleles per locus. The low $H_{E}$ value (0.2) obtained in our analysis is similar to that reported in a previous study (Costa et al., 2011) and suggested low genetic diversity in mangabeira populations. The polymorphic loci are important indicators of the level of genetic variation in a given area. A specimen with a high rate of polymorphism in the locus has a stronger capability for adaptation to environment, whereas one with a weaker capability will be eliminated by natural selection.

The Jaccard dissimilarity index and analysis of geographic distances indicated that the genetic variability was not spatially structured. This is probably due to the low number of markers 
used and the low genetic variability detected by the markers that were employed.

Classification of $H$. speciosa varieties is often hindered by the great morphological diversity of the species. Most taxonomists still use the Monachino (1945) classification, which identified six lineages for $H$. speciosa (speciosa, gardineri, pubescens, maximiliani, cuyabensis, and lundii). However, a recent reclassification (Koch et al., 2014) suggested that there were many synonymies and that mangabeira may be classified into only two lineages (speciosa and pubescens). We compared the genetic variability among the $H$. speciosa lineages and verified whether there was a significant difference in the botanical varieties evaluated. We observed a low divergence between the botanical varieties and an absence of specific fragments for different genotypes. In conclusion, the markers used in this study are not able to distinguish botanical varieties for $H$. speciosa.

The mangabeira is one of the fruiting trees that is most threatened with extinction in the Brazilian Cerrado and the Northeast, due to the large reduction in its distribution. The reduction has occurred as a result of deforestation, land speculation, and expansion of the agricultural frontier for grain crops and pastures (Lederman et al., 2000). It is necessary to characterize the distribution and the genetic composition of the different populations in order to outline conservation and breeding projects. Our contribution to this study was to identify reliable molecular markers to be used in future research and to show the low genetic variability among botanical varieties of $H$. speciosa.

\section{Conflicts of interest}

The authors declare no conflict of interest.

\section{ACKNOWLEDGMENTS}

The authors acknowledge the Brazilian funding agencies MCT/CNPq, FNDCT, CAPES, FINEP, FAPEG, and FUNAPEP. The authors also acknowledge Universidade Estadual de Goiás (UEG) for student scholarship and technological support.

\section{REFERENCES}

Almeida LM, Floriano JF, Ribeiro TP, Magno LN, et al. (2014). Hancornia speciosa latex for biomedical applications: physical and chemical properties, biocompatibility assessment and angiogenic activity. J. Mater. Sci. Mater. Med. 25: 2153-2162.

Carvalho PCL, Soares WS, Ritzinger R and Carvalho JABS (2002). Conservação de germoplasma de fruteiras tropicais com a participação do agricultor. Rev. Bras. Frutic. 24: 277-281.

Costa TS, Silva AVC, Lédo AS, Santos ARF, et al. (2011). Diversidade genética de acessos do banco de germoplasma de mangaba em Sergipe. Pesq. Agropec. Bras. 46: 499-507.

De Menezes IP, Gaiotto FA, Hoffman LV, Ciampi AY, et al. (2014). Genetic diversity and structure of natural populations of Gossypium mustelinum, a wild relative of cotton, in the basin of De Contas River in Bahia, Brazil. Genetica 142: 99-108.

Fan L, Zhang MY, Liu QZ, Li LT, et al. (2013). Transferability of newly developed pear SSR markers to other Rosaceae species. Plant Mol. Biol. Report 31: 1271-1282.

Ferreira HC, Serra CP, Lemos VS, Braga FC, et al. (2007a). Nitric oxide-dependent vasodilatation by ethanolic extract of Hancornia speciosa via phosphatidyl-inositol 3-kinase. J. Ethnopharmacol. 109: 161-164.

Ferreira HC, Serra CP, Endringer DC, Lemos VS, et al. (2007b). Endothelium-dependent vasodilation induced by Hancornia speciosa in rat superior mesenteric artery. Phytomedicine 14: 473-478.

González-Pérez MA, Sosa PA, Rivero E, González-González EA, et al. (2009). Molecular markers reveal no genetic differentiation between Myrica rivas-martinezii and M. faya (Myricaceae). Ann. Bot. 103: 79-86.

Koch I, Rapini A, Simões AO, Kinoshita LS, et al. (2014). Apocynaceae in Lista de Espécies da Flora do Brasil. Jardim Botânico do Rio de Janeiro. Available at [http://reflora.jbrj.gov.br/jabot/floradobrasil/FB15558]. Accessed Octuber 31, 2014.

Lal S, Mistry KN, Shah SD, Thaker R, et al. (2011). Genetic diversity assessment in nine cultivars of Catharanthus roseus from 
Central Gujarat (India) through RAPD, ISSR and SSR markers. J. Res. Biol. 8: 667-675.

Lederman IE, Silva Jr JF, Bezerra JEF and Espíndola ACM (2000). Mangaba (Hancornia speciosa Gomes). Funep, Jaboticabal.

Li LH, Hu FX, Chen WS, Cai WP, et al. (2012). Genetic diversity analysis of Penicillium marneffei isolated from AIDS patients in Guangdong, China using randomly amplified polymorphic DNA. Chin. Med. J. 125: 823-827.

Macedo M and Ferreira AR (2004). Plantas medicinais usadas para tratamentos dermatológicos, em comunidades da Bacia do Alto Paraguai, Mato Grosso. Rev. Bras. Farmacogn. 14: 40-44.

Madesis P, Abraham EM, Kalivas A, Ganopoulos I, et al. (2014). Genetic diversity and structure of natural Dactylis glomerata L. populations revealed by morphological and microsatellite-based (SSR/ISSR) markers. Genet. Mol. Res. 13: 4226-4240.

Marinho DG, Alviano DS, Matheus ME, Alviano CS, et al. (2011). The latex obtained from Hancornia speciosa Gomes possesses anti-inflammatory activity. J. Ethnopharmacol. 135: 530-537.

Mathithumilan B, Kadam NN, Biradar J, Reddy SH, et al. (2013). Development and characterization of microsatellite markers for Morus spp. and assessment of their transferability to other closely related species. BMC Plant Biol. 13: 194.

Mishra RK, Gangadhar BH, Yu JW, Kim DH, et al. (2011). Development and characterization of EST based SSR markers in Madagascar periwinkle (Catharanthus roseus) and their transferability in other medicinal plants. Plant Omics J. 4: 154-162.

Monachino JA (1945). A revision of Hancornia (Apocynaceae). Lilloa, Tucuman, 11: 19-48.

Moraes TM, Rodrigues CM, Kushima H, Bauab TM, et al. (2008). Hancornia speciosa: indications of gastroprotective, healing and anti-Heliobacter pylori actions. J. Ethnopharmacol. 120: 161-168.

Moura NF (2003). Estrutura genética de subpopulações de mangabeira (Hancornia speciosa Gomez) nos cerrados do Brasil Central. Doctoral thesis, Universidade Federal de Goiás. Goiânia.

Moura NF, Chaves JL, Venkovsky R, Zucchi MI, et al. (2005). Selection of RAPD markers to study genetic structure of Hancornia speciosa Gomes. Biosci. J. 21: 119-125.

Moura NF, Chaves JL, Venkovsky R, Naves RV, et al. (2011). Genetic structure of mangaba (Hancornia speciosa Gomes) populations in the cerrado region of central Brazil. Biosci. J. 27: 473-481.

Pan H, Yang C, Wei Z and Jiang J (2006). DNA extraction of birch leaves by improved CTAB method and optimization of its ISSR system. J. For. Res. 17: 298-300.

Peakall R and Smouse PE (2012). GenAlEx 6.5: genetic analysis in Excel. Population genetic software for teaching and research - an update. Bioinformatics 28: 2537-2539.

Perrier X and Jacquemoud-Collet JP (2006). DARwin software. Available at [http://darwin.cirad.fr/]. Accessed February 23, 2013.

Ritter MR, Sobierajski GR, Schenkel EP and Mentz LA (2002). Plantas usadas como medicinais no município de Ipê, RS, Brasil. Rev. Bras. Farmacogn. 12: 51-62.

Silva CG, Braga FC, Lima MP, Pesquero JL, et al. (2011). Hancornia speciosa Gomes induces hypotensive effect through inhibition of ACE and increase on NO. J. Ethnopharmacol. 137: 709-713.

Sneath PHA and Sokal RR (1973). Numerical taxonomy: the principles and practice of numerical classification. Freeman, San Francisco, 573.

Song SL, Lim PE, Phang SM, Lee WW, et al. (2014). Development of chloroplast simple sequence repeats (cpSSRs) for the intraspecific study of Gracilaria tenuistipitata (Gracilariales, Rhodophyta) from different populations. BMC Notes 7: 77.

Tamura K, Peterson D, Peterson N, Stecher G, et al. (2011). MEGA5: molecular evolutionary genetics analysis using maximum likelihood, evolutionary distance, and maximum parsimony methods. Mol. Biol. Evol. 28: 2731-2739.

Wang BH, Zhu P, Yuan YL, Wang CB, et al. (2014). Development of EST-SSR markers related to salt tolerance and their application in genetic diversity and evolution analysis in Gossypium. Genet. Mol. Res. 13: 3732-3746.

WWF (World Wide Fund for Nature) (2011). Cerrado, the Brazilian Savanna. Available at [http://wwf.panda.org/what_we_do/ where_we_work/cerrado/]. Accessed January 10, 2012.

Young A, Boyle T and Brown T (1996). The population genetic consequences of habitat fragmentation for plants. Trends Ecol. Evol. 11: 413-418.

Zucchi MI, Brondani RPV, Pinheiro JB, Brondani C, et al. (2002). Transferability of microsatellite markers from Eucalyptus spp. to Eugenia dysenterica (Myrtaceae family). Mol. Ecol. Notes 2: 512-513. 